\title{
Electrodeposition and Growth of Iron from an Ethylene Glycol Solution
}

\author{
Vusala Asim Majidzade, ${ }^{1, \star}$ Akif Shikhan Aliyev, ${ }^{1}$ Mahmoud Elrouby, ${ }^{2}$ \\ Dunya Mahammad Babanly ${ }^{1,3}$ and Dilgam Babir Tagiyev ${ }^{1}$ \\ ${ }^{1}$ Institute of Catalysis and Inorganic Chemistry named after M.Nagiyev, \\ Azerbaijan National Academy of Sciences, AZ1143, H.Javid 113 \\ ${ }^{2}$ Chemistry Department, Faculty of Science, Sohag University, 82524 Sohag, Egypt \\ ${ }^{3}$ French Azerbaijani University (UFAZ), AZ1010, Baku, Nizami 189 \\ *Corresponding author: E-mail: vuska_80@mail.ru
}

Received: 07-29-2020

\begin{abstract}
The electrochemical reduction of iron (III) ions into zero-valent iron from a solution of ethylene glycol was accomplished. The kinetics and mechanism of the electroreduction process were investigated by cyclic and linear polarization techniques. The influence of temperature, potential sweep rate, and concentration of iron (III) ions on the electroreduction process was also studied. The observed values of effective activation energy revealed that the investigated electroreduction process is accompanied by mixed kinetics control. Moreover, the results of SEM and X-ray diffraction analysis confirmed the deposition of thin Fe films under the optimized conditions.
\end{abstract}

Keywords: Polarization curves; chronoamperometry; iron ions; electroreduction; ethylene glycol.

\section{Introduction}

Currently, due to the decrease in natural energy sources, the use of environmentally friendly solar energy is very important. ${ }^{1-4}$

Iron disulfide $\left(\mathrm{FeS}_{2}\right)$ due to its non-toxicity and wide distribution on earth, it has the probability of becoming an inexpensive alternative material for fabricating highly efficient solar cells. ${ }^{5-10}$ Depending on its optical properties, it can be used in solar cells as a photoactive absorbing layer or as a frontal transparent layer in heterostructured cells. ${ }^{11}$ The preparation of these films has been carried out by various methods. The electrochemical deposition method has been used in this work, due to its simplicity to be optimized, and non-cost. For the co-electrodeposition of two or more components simultaneously, firstly the electrochemical reduction of each component should be studied individually. Therefore, this work aims to study the electrochemical reduction of iron ions, the kinetics, and the mechanism of the process in a non-aqueous solution of ethylene glycol.

The electroreduction and electrodeposition of iron ions have been reported. ${ }^{12-18}$ The results presented in the previously published work ${ }^{12}$ showed that the electrodeposition of iron in an acidic sulfate medium occurred, at least, through three adsorbed intermediates. It was observed that on the nonlinear part of the polarization curves, the electrodeposition of iron occurred, but with very low efficiency. In this area, the main cathodic reaction is the reduction of hydrogen, and low-efficient electrodeposition of iron was obtained through two intermediates. One of these adsorbed intermediates catalyzed the reduction of hydrogen, while the other blocked the process. The third intermediate appeared only at the potential region corresponding to the linear part of the polarization curves. It was also noted that the concentration of the adsorbed species at the surface strongly depends on the electrode potential.

The metallic Fe films onto a copper substrate from a mixture of $\mathrm{ChCl}$, urea, and $\mathrm{FeCl}_{3}$ has been previously electrodeposited. ${ }^{13}$ It was found that the use of direct current coating technology gives uniform, dense, gray, dull, and pure iron coatings. The electrodeposition at the ambient temperature produced iron films of high corrosion resistance and stable for several weeks. The surface morphology of the obtained iron films was also studied as a function 
of the applied current density. As a result, fine-grained and microcrystalline iron deposits without defects were obtained.

The influence of ammonium ion on the electrodeposition of iron from the iron sulfate bath was studied by other authors. ${ }^{14}$ During the cathodic polarization process in a solution of $0.02 \mathrm{M} \mathrm{FeSO}_{4}$ at $\mathrm{pH}=3$ by using the quartz crystals microbalance technique, the presence of ammonium sulfate increased the mass of the electrodeposited Fe metal. The obtained $\mathrm{pH}$ (at the surface of the working electrode) - potential curves showed that in the presence of ammonium sulfate, the $\mathrm{pH}$ simultaneously increased to the alkaline levels during the electrolysis process. These results suggest that ammonium ion facilitates the formation of ammoniated ferrous iron (e.g., $\mathrm{Fe}\left(\mathrm{NH}_{3}\right)_{2}{ }^{2+}$ and $\left.\mathrm{Fe}\left(\mathrm{NH}_{3}\right)_{4}{ }^{2+}\right)$. This prevents the deposition of $\mathrm{Fe}(\mathrm{OH})_{2}$ on the electrode, which can lead to passivation of the surface and, therefore, to a limited deposition of Fe metal.

Nanocrystalline iron was electrodeposited from 1-butyl-1-methylpyrrolidinium bis (trifluoromethylsulfonyl) amide ([Py1,4] TFSA) ionic liquid at $100{ }^{\circ} \mathrm{C} .{ }^{15}$ The electrodeposition of iron from ([Py1,4] TFSA) was accomplished by using $\mathrm{Fe}(\mathrm{TfO})_{2}$ and $\mathrm{FeCl}_{2}$ as precursors. Cyclic voltammetry was used to investigate the electrochemical behavior of $\mathrm{FeCl}_{2}, \mathrm{Fe}(\mathrm{TfO})_{2}$, and $\left(\mathrm{FeCl}_{2}+\mathrm{AlCl}_{3}\right)$ in the presence of ionic liquid as a supporting electrolyte. But, a thick iron film was obtained from $\mathrm{FeCl}_{2} /[\mathrm{Py} 1,4] \mathrm{TfO}$ at these conditions.

Iron metal films were also electrodeposited on copper substrates by the galvanostatic method at various $\mathrm{pH}$, temperature, and current density from weak acidic $(\mathrm{pH}=$ 5.7) solutions containing iron sulfate and sodium gluconate. ${ }^{16}$ It was found that the optimal conditions for obtaining stable $\mathrm{Fe}$ films are as follows; a solution consists of $0.038 \mathrm{~mol} \cdot \mathrm{dm}^{3} \mathrm{Fe}_{2}\left(\mathrm{SO}_{4}\right)_{3} .7 \mathrm{H}_{2} \mathrm{O}$ and $0.14 \mathrm{~mol} \cdot \mathrm{dm}^{3}$ sodium gluconate, at current density $(\mathrm{j})=0.33 \mathrm{~A} / \mathrm{cm}^{2}, \mathrm{pH}=$ 5.7 , and temperature $25^{\circ} \mathrm{C}$. The obtained Fe films from this electrolyte have a single-phase crystal structure.

The polarization curves for the discharge of iron and hydrogen ions during the electrolysis of sulfate solutions with various concentrations of amino-acetic acid showed that the presence of glycine in the electrolyte inhibited both the discharge of iron and hydrogen ions. ${ }^{17}$ The obtained results showed that the current efficiency of the iron electrodeposition depends linearly upon the concentration of glycine passes. The influence of $\mathrm{pH}$ and temperature on the quality of the coating was also investigated. From the previous work, the optimum conditions for obtaining a high-quality deposit were as follows; sulfate electrolyte containing $0.1-0.15 \mathrm{M}$ glycine, $\mathrm{pH}=1.9-0.1$, temperature $20{ }^{\circ} \mathrm{C}$, and current density $(\mathrm{j})=20 \mathrm{~mA} / \mathrm{cm}^{2}$ should be applied.

The electrodeposition of iron metal was also studied from the ether solution. ${ }^{18}$ The electrodeposition bath consisted of iron (II) chloride $\left(\mathrm{FeCl}_{2}\right)$, diglyme (G2) as a complexing agent, and aluminum chloride $\left(\mathrm{AlCl}_{3}\right)$. The effect of hydrogen gas evolution on the morphology of iron deposits was investigated by using different aqueous electrolytes. A thin Fe film was obtained using $\mathrm{FeCl}_{2}-\mathrm{G}_{2}-\mathrm{AlCl}_{3}$ in the absence of the hydrogen gas evolution, and the nucleation of iron was explained by the instant nucleation mechanism. As a result, the surface morphology of the thin Fe film was found to be compact and smooth compared to that obtained from aqueous and nonaqueous electrolytes.

M.A. Miller et. al. ${ }^{19}$ used ethylene glycol as an electrolyte but in the presence of choline chloride $(\mathrm{ChCl})$ and $\mathrm{FeCl}_{2}$ that gave different behavior and results compared with the present work. They also used different ratios from ChCl:EG: $\mathrm{FeCl}_{2}$ and obtained different results at each ratio. But in the present work, EG and $\mathrm{Fe}\left(\mathrm{NO}_{3}\right)_{3}$ were used, where nitrates salts have a considerable solubility compared with chloride and other salts. Furthermore, the electrodeposition process was accomplished at room temperature and not at $80^{\circ} \mathrm{C}$. S. Higashino et. al. ${ }^{20}$ used $\mathrm{FeCl}_{3}$ as a precursor in presence of acetamide as a complexing agent that gave different results compared with our work.

According to the published literature, the kinetics and mechanism of the electrochemical deposition of iron from different aqueous electrolytes were studied. Therefore, our work aims to study the kinetics and mechanism of the electroreduction of iron ions from non-aqueous electrolytes (using ethylene glycol). The current work is considered to be one from a series of our works on the electrochemical synthesis of chalcogenide compounds. ${ }^{21-23}$

\section{Experimental Part}

The electrolyte for the electrochemical reduction of iron (III) ions was prepared as follows: an appreciated amount of $\mathrm{Fe}\left(\mathrm{NO}_{3}\right)_{3} \cdot 9 \mathrm{H}_{2} \mathrm{O}$ was dissolved in ethylene glycol by stirring in the temperature range of $313-323 \mathrm{~K}$ to give $0.1 \mathrm{M}$. Polarization and chrono-amperometric curves were accomplished by a potentiostat IVIUMSTAT electrochemical interface. An electrochemical three-electrode cell with a capacity of $100 \mathrm{ml}$ was used. A Pt sheet with an area of $3 \times 10^{-3} \mathrm{dm}^{2}$ and a Ni sheet with an area of $2 \mathrm{~cm}^{2}$ were used as working electrodes. The silver chloride electrode was used as a reference electrode and the platinum sheet with an area of $4 \mathrm{~cm}^{2}$ as an auxiliary electrode. The UTU-4 universal ultra-thermostat was utilized to regulate the temperature in the bath of the electrolytic cell.

The phase composition of the obtained thin films was analyzed using a Bruker D2 Phaser X-ray diffractometer $\left(\mathrm{CuK}_{\alpha}\right.$; Ni filter). The morphology and chemical elemental composition of the samples were determined by Carel Zeiss Sigma scanning electron microscopy (SEM).

At the beginning of the experiments, the surface of Pt electrodes was cleaned in concentrated nitric acid and then washed with bidistilled water. Furthermore, after each experiment, the Pt electrodes were kept in boiling ni- 
tric acid for 30 minutes. This is necessary to get rid of the adsorbed small amounts of ferric chloride on the electrode surface. After that, they were washed thoroughly with ordinary water, then with distilled water, and finally rinsed with alcohol or acetone. Ni electrode was subjected to electrochemical polishing in a solution consists of $\mathrm{H}_{2} \mathrm{SO}_{4}$, $\mathrm{H}_{3} \mathrm{PO}_{4}$, and citric acid $\left(\mathrm{T}=293-303 \mathrm{~K}, \mathrm{i}=50 \mathrm{~A} / \mathrm{dm}^{2}, \tau=\right.$ 180 seconds), and was washed with bidistilled water.

\section{Results and Discussion}

The study of the electroreduction of iron ions (III) from non-aqueous solutions was carried out by the potentiodynamic method. As can be seen from Figure 1, the electrochemical reduction of iron (III) ions at the cathode occurred in two stages within the potential range of 0.8 $(-1.2) \mathrm{V}$. The first stage (I) was observed at the potential range of $0.8-(-0.36) \mathrm{V}$ that shows the reduction of $\mathrm{Fe}$ (III) to $\mathrm{Fe}$ (II) as in the following reaction: $\mathrm{Fe}^{3+}+\mathrm{e}^{-}=\mathrm{Fe}^{2+}$.

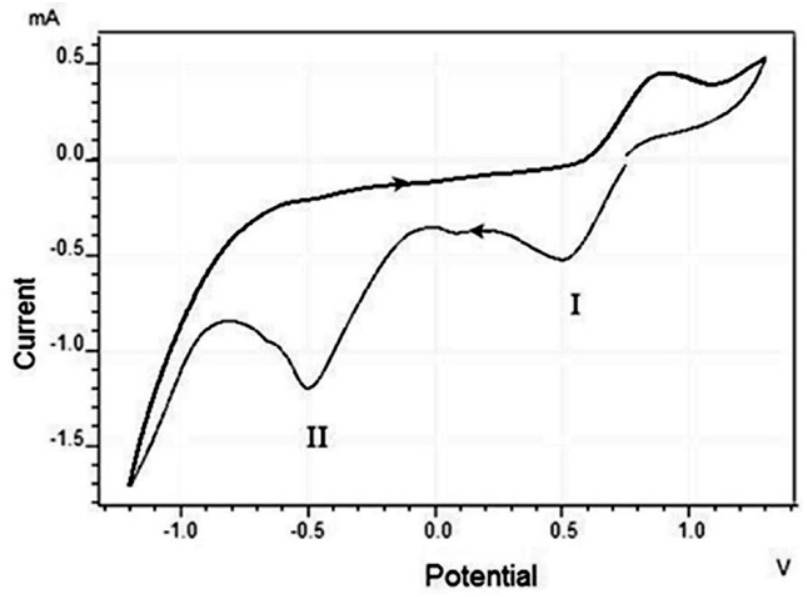

Fig. 1. Cyclic voltammetric curves of the electroreduction of iron (III) ions on a Pt electrode in a non-aqueous medium. The electrolyte composition in (M): $0.1 \mathrm{M} \mathrm{Fe}\left(\mathrm{NO}_{3}\right)_{3} \cdot 9 \mathrm{H}_{2} \mathrm{O}+\mathrm{CH}_{2} \mathrm{OH}-\mathrm{CH}_{2} \mathrm{OH}$; at $\mathrm{T}=293 \mathrm{~K}$, and $\mathrm{E}_{\mathrm{V}}=0.02 \mathrm{~V} / \mathrm{s}$.
The second stage corresponds to the reduction of $\mathrm{Fe}$ (II) to the atomic iron in the potential range of -0.36$(-0.8) \mathrm{V}$, which agreed with previously published work. ${ }^{24}$ After the potential value of $-0.8 \mathrm{~V}$, iron is deposited on the substrate.

To study the kinetics of the electroreduction of iron (III) ions, polarization curves of a linear nature were recorded depending on the temperature at a temperature range of $288-348 \mathrm{~K}$. As can be seen from Fig. 2, the potential of the electroreduction of iron (III) ions moves towards a positive direction and the current increases due to the ion mobility which increases with increasing the temperature. With the aid of these polarizing curves, the dependence of $\lg _{\mathrm{k}}$ on $1 / \mathrm{T}$ in the potential interval of $0.0-(-0.5)$ $\mathrm{V}$ was depicted as in Fig. 3(a), and the value of tga was calculated from the obtained curves. The value of the effective activation energy was calculated using the equation of $A_{\text {eff. }}=2.3 \mathrm{Rtg} \alpha$. The values of $A_{\text {eff }}$ showed that the electroreduction of iron ions (III) from non-aqueous electrolytes is accompanied by mixed kinetics. In the potential range of

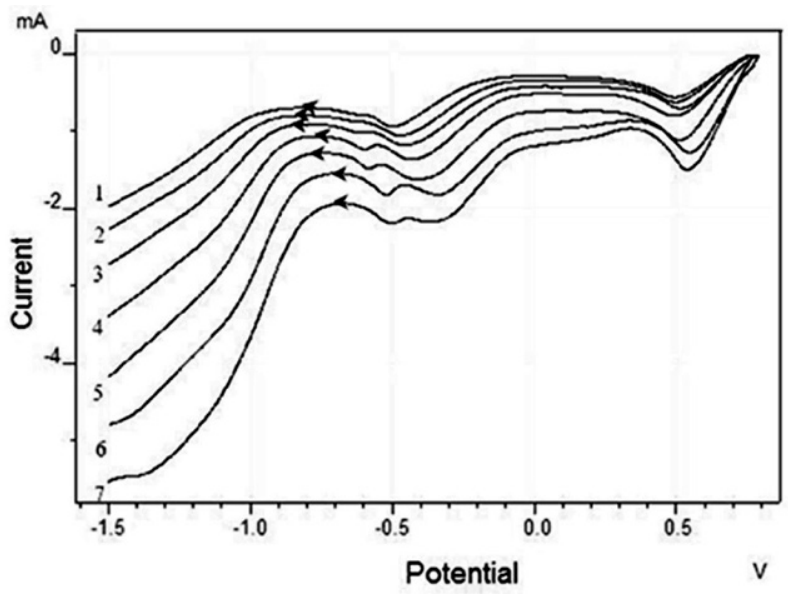

Fig. 2. The effect of temperature on the electroreduction of iron (III) ions. The electrolyte composition in (M): $0.1 \mathrm{Fe}\left(\mathrm{NO}_{3}\right)_{3} \cdot 9 \mathrm{H}_{2} \mathrm{O}+$ $\mathrm{CH}_{2} \mathrm{OH}-\mathrm{CH}_{2} \mathrm{OH}$; at different $\mathrm{T}(\mathrm{K}): 1$ - 288; 2- 298; 3- 308; 4- 318; 5- 328; 6- 338; 7- 348, and scan rate $\mathrm{E}_{\mathrm{V}}=0.02 \mathrm{~V} / \mathrm{s}$
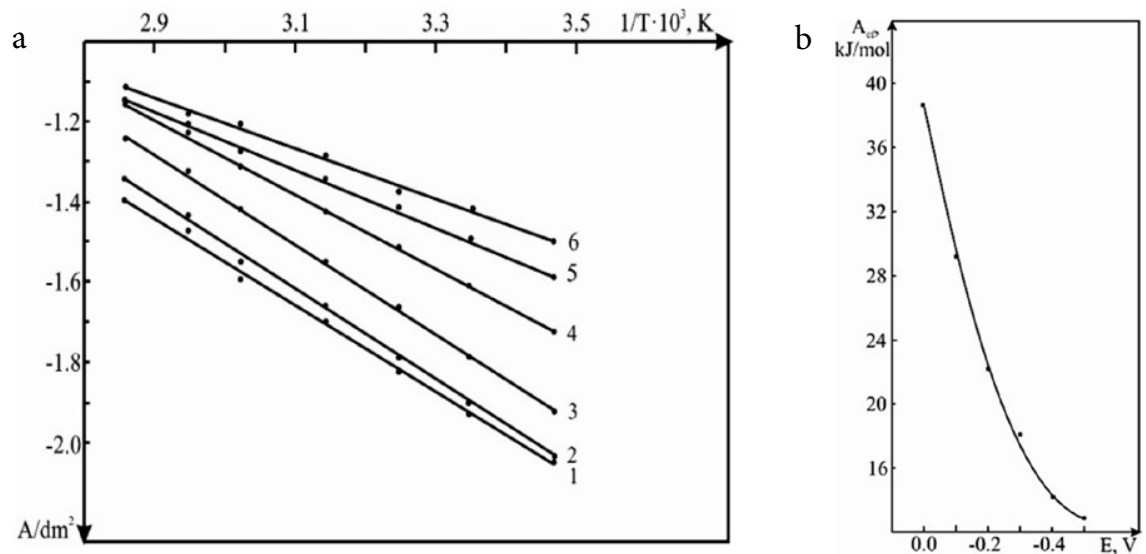

Fig. 3. (a) $\operatorname{lgi}_{\mathrm{k}}-1 / \mathrm{T}$ dependence, at different $\mathrm{E}(\mathrm{V})=1-0.0 ; 2-(-0.1) ; 3-(-0.2) ; 4-(-0.3) ; 5-(-0.4) ; 6-(-0.5)$. (b) Dependence of the activation energy upon the electrode potential. 
$0.0-(-0.2) \mathrm{V}$ the process proceeds under electrochemical polarization control, and after $-0.2 \mathrm{~V}$ under concentration polarization control (Fig. $3 \mathrm{~b}$ ).

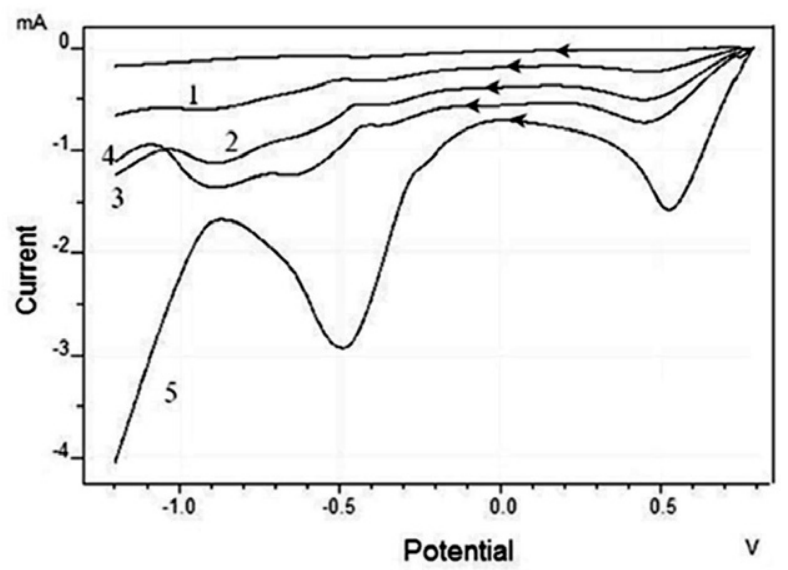

Fig. 4. The influence of the concentration of iron (III) ions on the electroreduction process on the $\mathrm{Pt}$ electrode. The electrolyte composition in (M): $\mathrm{Fe}\left(\mathrm{NO}_{3}\right)_{3} \cdot 9 \mathrm{H}_{2} \mathrm{O}+\mathrm{CH}_{2} \mathrm{OH}-\mathrm{CH}_{2} \mathrm{OH} ; 1-0.005 ; 2$ $0.05 ; 3-0.1 ; 4-0.15 ; 5-0.2$. At $\mathrm{T}=293 \mathrm{~K}$, and $\mathrm{E}_{\mathrm{V}}=0.02 \mathrm{~V} / \mathrm{s}$

The effect of concentration on the electroreduction of iron (III) ions has been also studied. Polarization curves at different concentrations of iron (III) ions are presented as in Fig. 4. As can be seen from the curves, the cathodic current of iron electrodeposition increases from -0.2 to $-4.1 \mathrm{~mA}$ with the increase of the $\mathrm{Fe}^{3+}$ concentration in the electrolyte. Moreover, the reduction potential is shifted to the positive direction up to $0.05 \mathrm{~V}$. This can be explained on the basis that, with an increase in the concentration of iron (III) ions in the electrolyte, the migration rate of these ions to the electrode increases, and hence electroreduction occurs faster than that of the previous concentration.

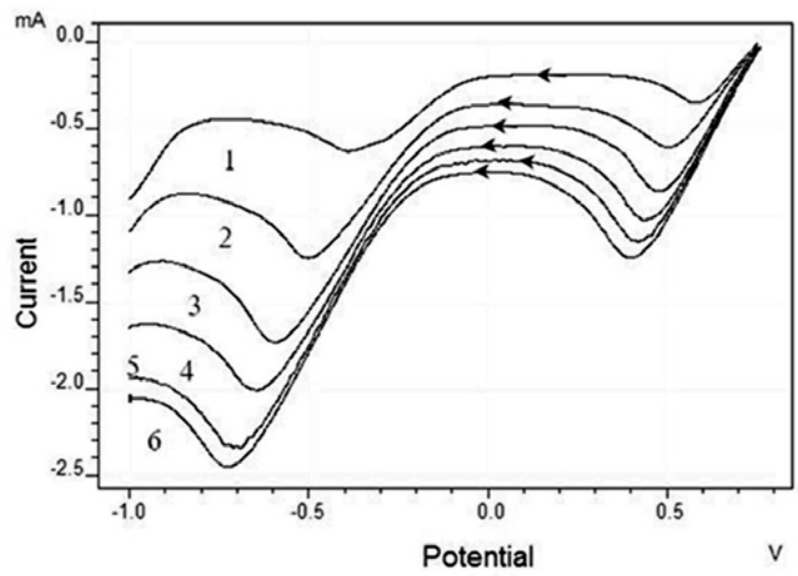

Fig. 5. The effect of the scan rate on the electroreduction of iron (III) ions. Electrolyte composition in (M): $0,1 \mathrm{Fe}\left(\mathrm{NO}_{3}\right)_{3} \cdot 9 \mathrm{H}_{2} \mathrm{O}+$ $\mathrm{CH}_{2} \mathrm{OH}-\mathrm{CH}_{2} \mathrm{OH}$. Scan rate (V/s): $1-0,005 ; 2-0,02 ; 3-0,04 ; 4-0,06$; 5- 0,$08 ; 6-0,1$. At $\mathrm{T}=293 \mathrm{~K}$.
The influence of the scan rate on the electroreduction of iron (III) ions was also studied. Fig. 5 exhibits the cathodic potentiodynamic polarization curves of the process. As can be seen from Fig. 5, with an increase in the potential scan rate, the cathodic current of the electroreduction of iron (III) ions increase:, the cathodic current was $-9.11 \times 10^{-4} \mathrm{~A}$ at $0.005 \mathrm{~V} / \mathrm{s}$ and $-27.60 \times 10^{-4} \mathrm{~A}$ at 0.1 $\mathrm{V} / \mathrm{s}$.

The chronoamperometric (CA) method was used for obtaining more precise information about the electrochemical deposition process, at which the potential can be fixed at the deposition potential. Mechanisms of the nucleation and growth of the electrodeposited particles can be investigated via CA method. Current-time curves were accomplished at different applied potentials; $-0.40,-0.45$, $-0.50,-0.55$, and $-0.60 \mathrm{~V}$ at room temperature as shown in Fig. 6. It seems from the shown figure that the initial regime of the current-time curve is characterized by a sudden decrease in the current under application of the deposition potential. This can be attributed to the presence of the double-layer between the surface of the substrate and the ions of the solution, which lead to the formation of immediate nucleation of iron in all cases (Fig. 6).

This sudden decrease is followed by a little increase in the resultant current. This is due to an increase in the electroactive surface area which correlated with the crystal growth. It can be noted that during the electrodeposition, in all cases, the current density increases by increasing the deposition potential. The mechanism of crystal nucleation and growth can be determined by the analysis of the obtained current-time curves.

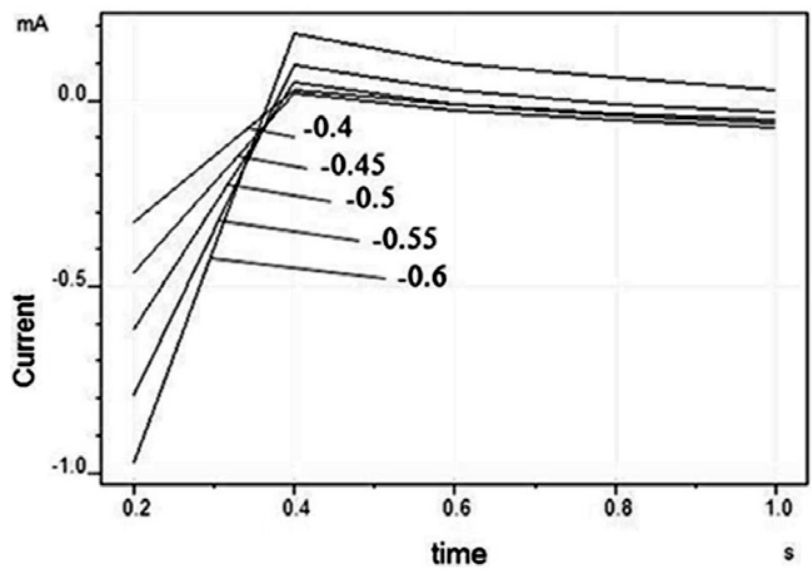

Fig. 6. Current-time curves of the electrodeposition of iron on $\mathrm{Pt}$ in the electrolyte of the $0.1 \mathrm{Fe}\left(\mathrm{NO}_{3}\right)_{3} \cdot 9 \mathrm{H}_{2} \mathrm{O}+\mathrm{CH}_{2} \mathrm{OH}-\mathrm{CH}_{2} \mathrm{OH}$ composition at room temperature and different deposition potentials: $-0.4 ;-0.45 ;-0.5 ;-0.55$; and $-0.6 \mathrm{~V}$ vs. $\mathrm{Ag} / \mathrm{AgCl}$.

The analysis of these curves can be achieved by applying the two equations of Scharifker-Hills ${ }^{25}$ compared with the experimental calculated data as shown in Fig. 7 (a-e). The models of the theoretical transients for the in- 
stantaneous and the progressive 3D nucleation are given by equations (1) and (2), respectively:

$$
\begin{aligned}
& \frac{I(t)^{2}}{I_{\max }}=\frac{1.9542}{t / t_{\max }}\left\{1-\exp \left[-1.2564\left[\frac{t}{t_{\max }}\right]\right]\right\}^{2} \\
& \frac{I(t)^{2}}{I_{\max }}=\frac{1.2254}{t / t_{\max }}\left\{1-\exp \left[-2.3367\left[\frac{t}{t_{\max }}\right]^{2}\right]\right\}^{2}
\end{aligned}
$$
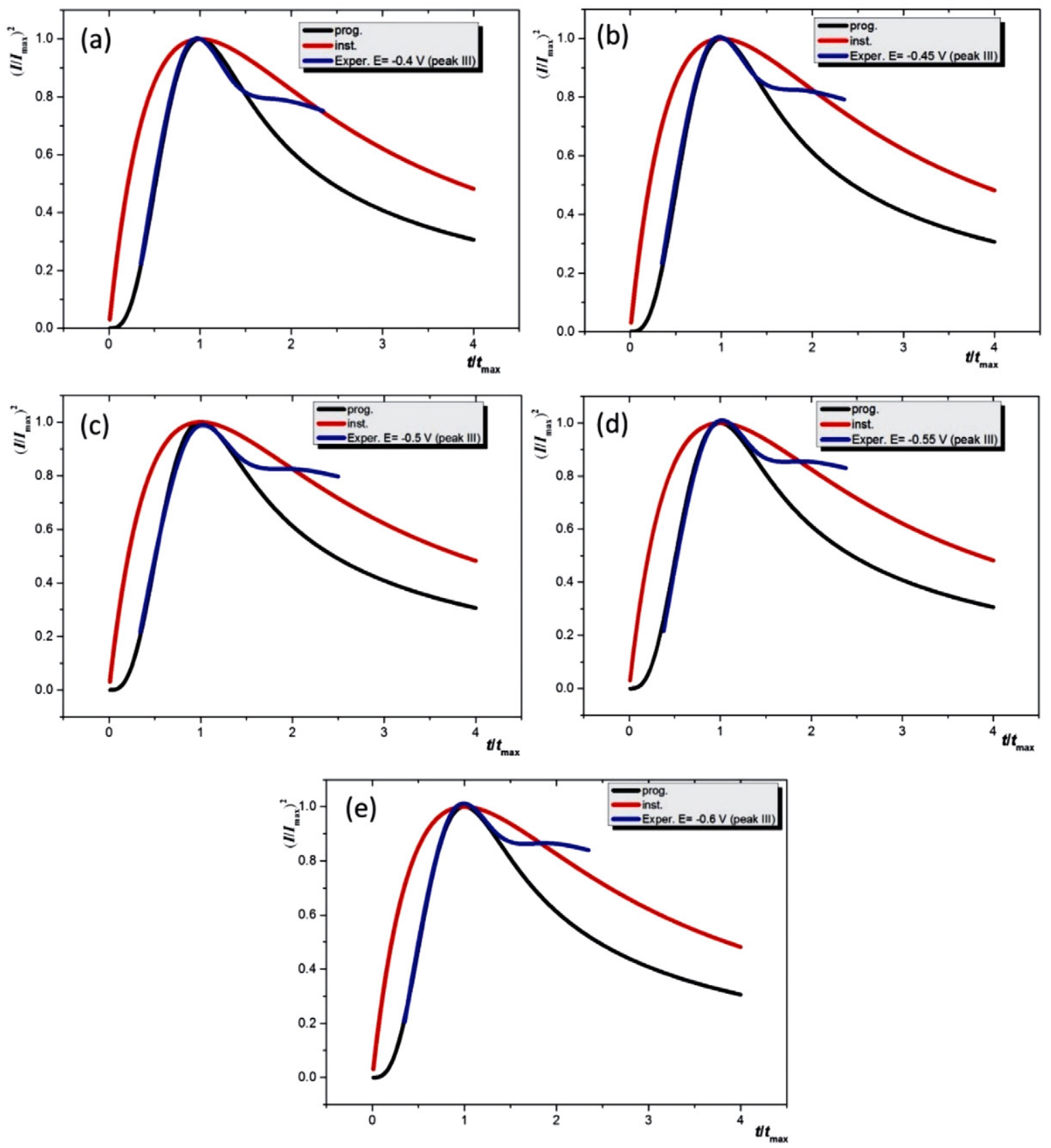

Fig. 7. Comparison of the theoretical non-dimensional $\left(\mathrm{I} / \mathrm{I}_{\max }\right)^{2} \mathrm{vs}\left(\mathrm{t} / \mathrm{t}_{\max }\right)$ plots for instantaneous (red) and progressive (black) nucleation with experimental data (blue) of potentiostatic transients in the solution of $0.1 \mathrm{Fe}\left(\mathrm{NO}_{3}\right)_{3} \cdot 9 \mathrm{H}_{2} \mathrm{O}+\mathrm{CH}_{2} \mathrm{OH}-\mathrm{CH}_{2} \mathrm{OH}$ at different constant potentials: (a) -0.4 , (b) -0.45 , (c) -0.50 , (d) -0.55 and (e) $-0.6 \mathrm{~V}$ 
quently, the deposition deviates from the progressive nucleation as shown in Fig. 7 (a, b, c, d, and e). The deviation from the ideal assumption of the Scharifker model may be attributed to that the nuclei grow under diffusion control at these conditions.

Bypassing time through the nuclei growth, the electrodeposition of iron will be under mixed control (diffusion and charge transfer). The deviation can be also interpreted as due to the hydrogen evolution reaction during the formation of nuclei which causes a morphology change of the nucleus. Further information for the growth mechanism can be obtained by calculating the density of actives sites for nucleation $\left(\mathrm{N}_{0}\right)$ by using the following equation;

$$
N_{0}=0.065\left(\frac{8 \pi C M}{\rho}\right)^{-1 / 2}\left(\frac{z f C}{t_{\max } i_{\max }}\right)^{2}
$$

where, $\mathrm{C}$ is the bulk concentration in $\mathrm{mol} \mathrm{cm}{ }^{-3}$, $\mathrm{zf}$ the molar charge of electrodepositing species, $\mathrm{M}$ and $\rho$ are the molar mass and the density of the deposited material in $\mathrm{g}$ $\mathrm{cm}^{-3}$, respectively. The diffusion coefficient $\mathrm{D}$ of the active species in the electrolyte can be calculated via the chronoamperometric method. According to the theoretical nucleation model, the $\mathrm{D}$ is related to the $\mathrm{i}_{\max }$ and the $\mathrm{t}_{\max } 25,26$ by the following equation;

$$
\mathrm{D}=\frac{\mathrm{i}_{\max }{ }^{2} \mathrm{t}_{\max }}{0.1629(\mathrm{zfC})}
$$

The values of $i_{\max }, t_{\max }, D$, and $N_{0}$ at different deposition potentials are shown in Table 1 . The $\mathrm{D}$ values of the electroactive species are very small at these conditions, which is due to the high relative density of the electrolyte and the high relative diameter of iron ions. Therefore, the diffusion of iron ions from the bulk of the electrolyte towards the polarized electrode will be very small. Accordingly, the process is controlled by the diffusion step. Also, the value of $\mathrm{D}$ is a function of the polarization potential as listed in Table 1.

It is noted from the table that nuclei densities $\mathrm{N}_{0}$ decrease significantly with the increase of the deposition potential. This decrease is due to the decrease of the activation of the nucleation sites at higher potentials, which deviates from the classical nucleation models as confirmed by Fig. 6 . This deviation can also be explained as, by in-

Table 1. Experimental data on the electrodeposition of Fe on a Pt electrode

\begin{tabular}{ccc}
\hline E, V & $\mathbf{D}, \mathbf{c m}^{\mathbf{2}} \mathbf{~ s}^{\mathbf{1}}$ & $\mathbf{N}_{\mathbf{o}}, \mathbf{c m}^{\mathbf{2}}$ \\
\hline-0.40 & $1.429 \times 10^{-17}$ & $5.00 \times 10^{15}$ \\
-0.45 & $6.556 \times 10^{-18}$ & $10.09 \times 10^{15}$ \\
-0.50 & $3.619 \times 10^{-17}$ & $1.98 \times 10^{15}$ \\
-0.55 & $1.468 \times 10^{-16}$ & $0.49 \times 10^{15}$ \\
-0.60 & $5.240 \times 10^{-16}$ & $0.14 \times 10^{15}$ \\
\hline
\end{tabular}

creasing the deposition potential the polarization of the working electrodes increases. But the diffusion of the active species is still slow because of the high density of surrounding media which hinders the diffusion of the active species.

The data of the XRD pattern (Fig. 8) and SEM images (Fig. 9) confirmed the obtained films of the electrodeposited iron on the Ni electrode.

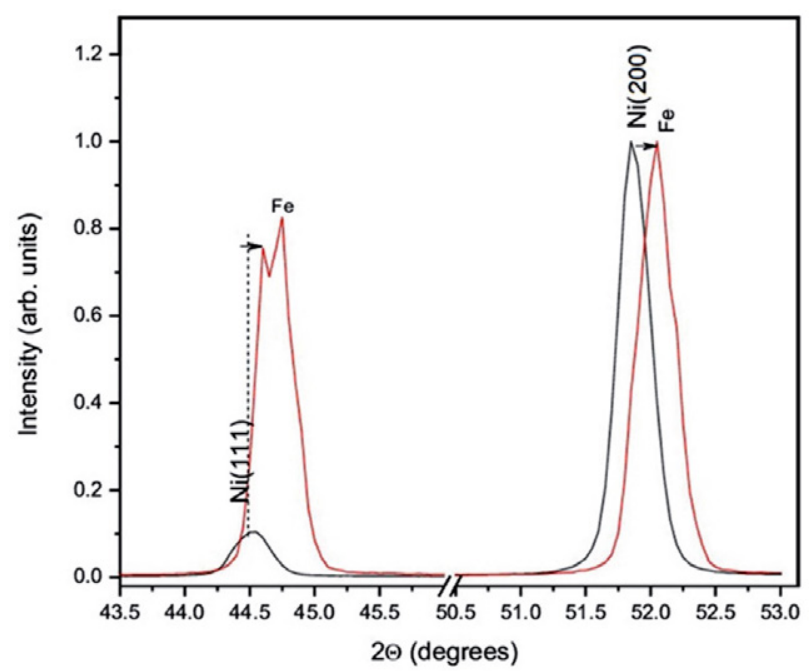

Fig. 8. The results of the $\mathrm{XRD}$ analysis of electrodeposited iron from $0.1 \mathrm{M} \mathrm{Fe}\left(\mathrm{NO}_{3}\right)_{3} \times 9 \mathrm{H}_{2} \mathrm{O}+\mathrm{CH}_{2} \mathrm{OH}-\mathrm{CH}_{2} \mathrm{OH}$ electrolyte on the $\mathrm{Ni}$ electrode. $\mathrm{E}_{\mathrm{V}}=0.02 \mathrm{~V} / \mathrm{s}, \mathrm{T}=293 \mathrm{~K}$.
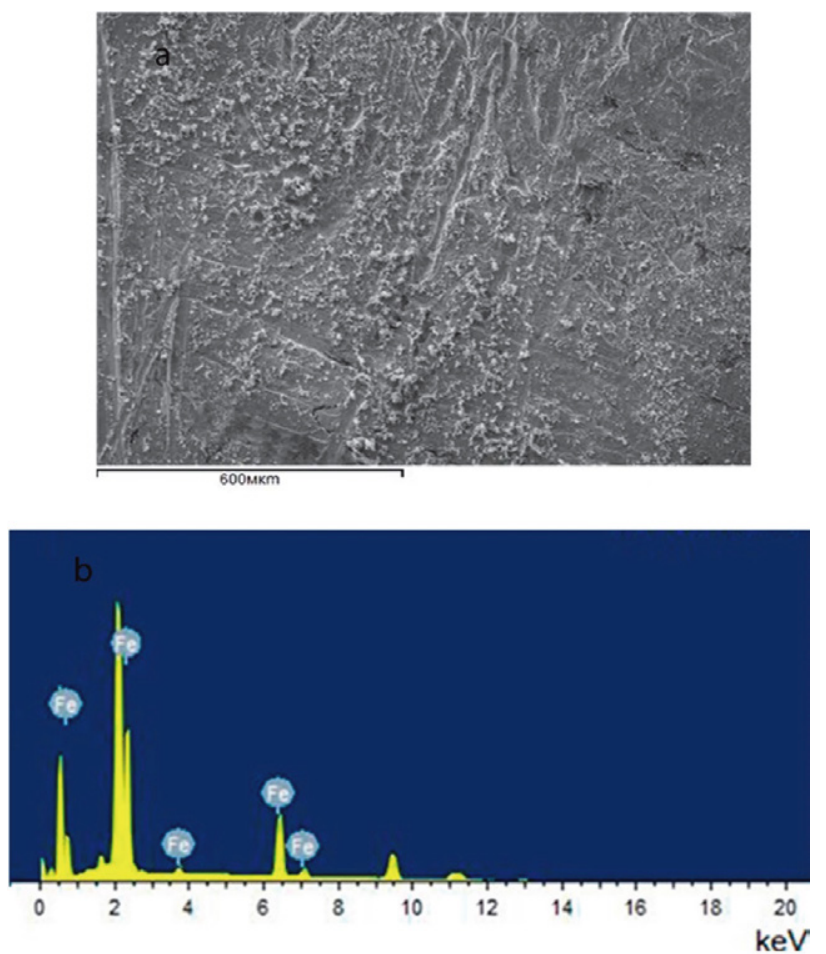

Fig. 9. The image of SEM (a) and EDAX analysis (b) of electrodeposited iron from the $0.1 \mathrm{M} \mathrm{Fe}\left(\mathrm{NO}_{3}\right)_{3} \times 9 \mathrm{H}_{2} \mathrm{O}+\mathrm{CH}_{2} \mathrm{OH}-\mathrm{CH}_{2} \mathrm{OH}$ electrolyte on the Ni electrode. At $\mathrm{E}_{\mathrm{V}}=0.02 \mathrm{~V} / \mathrm{s}$, and $\mathrm{T}=293 \mathrm{~K}$. 
The SEM image showed that the nickel substrate is well coated. It seems to be relatively homogeneous and has a few cracks (Fig. 9). However, judging by the obtained $\mathrm{X}$-ray pattern, these coatings are very thin (Fig. 8). It is noted that nickel peaks are also shifted towards large diffraction angles $(2 \theta)$. This is because of a slight contraction of the modified crystal lattice, which is due to the incorporation of iron atoms into the nickel lattice. All experimental results exhibit that, in order to achieve the process and obtain compact, smooth deposits, an optimal electrolyte composition of $0.1 \mathrm{M} \mathrm{Fe}\left(\mathrm{NO}_{3}\right) \cdot 9 \mathrm{H}_{2} \mathrm{O}+\mathrm{CH}_{2} \mathrm{OH}-\mathrm{CH}_{2} \mathrm{OH}$, at $293 \mathrm{~K}$, and a potential range of $0.6-(-0.9) \mathrm{V}$ should be applied.

\section{Conclusion}

Electrochemical reduction of iron (III) ions on $\mathrm{Pt}$ electrode from ethylene glycol solution was studied by the potentiodynamic method. During the study of kinetics and mechanism of the process by the cyclic and linear polarization curves, it was revealed that the nature of polarization is accompanied by mixed kinetics. It is worth mentioning that, in the potential range of $0.0-(-0.2) \mathrm{V}$, the process proceeds under electrochemical polarization control, whereas after $-0.2 \mathrm{~V}$ it is controlled by concentration polarization. The obtained results show that the electroreduction of iron (III) ions is affected by concentration, temperature, and the potential scan rate. From these results, the optimal mode and composition of the electrolyte for the preparation of the compact and smooth iron films have been detected. SEM and XRD data confirm the electrodeposition of thin Fe films.

\section{References}

1. MR Palacín, P Simon, JM Tarascon, Acta Chim. Slov. 2016, 63, 417-423. DOI:10.17344/acsi.2016.2314

2. VN Fateev, OK Alexeeva, SV Korobtsev, EA Seregina, TV Fateeva, AS Grigoriev, ASh Aliyev, Chemical Problems. 2018, 4, 453-483. DOI:10.32737/2221-8688-2018-4-453-483

3. TL Kulova, II Nikolaev, VN Fateev, ASh Aliyev, Chemical Problems. 2018, 1, 9-34.

DOI:10.32737/2221-8688-2018-1-9-34

4. VN Fateev, TL Kulova, EA Seregina, NA Ivanova, DD Spasov, Chemical Problems. 2019, 3, 349-357.

DOI:10.32737/2221-8688-2019-3-349-357

5. V Aluri, KTR Reddy, YM Reddy, Nanotechnol. Rev. 2015, 4, 469-472. DOI:10.1515/ntrev-2014-0043

6. X Wang, G Wang, J Chen, X Zhu, J Tian, C Jiang, Y Zhang, X Liu, R Wang, Mater. Lett. 2013, 110, 144-147.

DOI:10.1016/j.matlet.2013.07.107

7. A Gomes, JR Ares, IJ Ferrer, MI da Silva Pereira, C Sanchez, Mater. Res. Bull. 2003, 38, 1123-1133.

DOI:10.1016/S0025-5408(03)00116-8
8. YZ Dong, YF Zheng, H Duan, YF Sun, YH Chen, Mater. Lett. 2005, 59, 2398-2402. DOI:10.1016/j.matlet.2005.03.025

9. YZ Dong, YF Zheng, XG Zhang, H Duan, YF Sun, YH Chen, Sci. China Technol. Sci. 2005, 48, 601-611.

DOI:10.1360/102004-32

10. S Nakamura, A Yamamoto, Sol. Energy Mater. Sol. Cells. 2001, 65, 79-85. DOI:10.1016/S0927-0248(00)00080-5

11. IG Orletskii, PD Mar'yanchuk, EV Maistruk, MN Solovan, VV Brus, Phys. Solid State. 2016, 58, 37-41. DOI:10.1134/S1063783416010224

12. SL D'raz, JA Caldero'n, OE Barcia, OR Mattos, Electrochim. Acta. 2008, 53, 7426-7435.

DOI:10.1016/j.electacta.2008.01.015

13. R Böck, S-E Wulf, Trans. Jnst. Met. Fin. 2009, 87, 28-32. DOI:10.1179/174591908X379601

14. M Deelo, K Weil, KA Osseo-Asare, In Electrochem. in Miner. Metal Proc. VII. 2006, 293-303. DOI: $10.1179 / 174591908 X 379601$

15. P Giridhar, B Weidenfeller, El Abedin S Zein, F Endres, Phys. Chem. Chem. Phys. 2014, 16, 9317-9326.

DOI:10.1039/c4cp00613e

16. SS Abd El Rehin, EA Abd El Meguid, EM Moustafa, Trans. Jns. Met. Fin. 2003, 81, 79-82.

DOI:10.1080/00202967.2003.11871503

17. NV Evreinova, IA Shoshina, VN Naraev, KI Tikhonov, Russ. J. of Appl. Chem. 2008, 81, 1180-1183.

DOI:10.1134/S1070427208070100

18. Z Zhang, A Kitada, K Fukami, Z Yao, K Murase, Electrochim. Acta. 2020, 348, 136289.

DOI:10.1016/j.electacta.2020.136289

19. MA Miller, JS Wainright, RF Savinell, J. Electrochem. Soc. 2017, 164 (4), A796-A803. DOI:10.1149/2.1141704jes

20. S Higashino, AP Abbott, M Miyake, T Hirato, Electrochim. Acta 2020, 351, 136414. DOI:10.1016/j.electacta.2020.136414

21. VA Majidzade, SP Mammadova, ES Petkucheva, E P Slavcheva, ASh Aliyev, DB Tagiyev, Bulg. Chem. Commun. 2020, 52 Special Issue E, 73 - 78

22. VA Majidzade, PH Guliyev, ASh Aliyev, M Elrouby, DB Tagiyev, J. Mol. Struc. 2017, 1136, 7-13.

DOI:10.1016/j.molstruc.2017.01.082

23. VA Majidzade, ASh Aliyev, DM Babanly, M Elrouby, DB Tagiyev, Acta Chim. Slov. 2019, 66, 155-162.

DOI:10.17344/acsi.2018.4733

24. AA Sukhotin (Ed): Handbook of Electrochemistry, Chemistry, Leningrad, Russian, 1981, p. 488.

25. B Scharifker, G Hills, Electrochim. Acta. 1983, 28, 7, 879889. DOI:10.1016/0013-4686(83)85163-9

26. MR Khelladi, L Mentar, A Azizi, A Sahari, A Kahoul, Mater. Chem. Phys. 2009, 115, 385-390.

DOI:10.1016/j.matchemphys.2008.12.017 


\section{Povzetek}

Dosegli smo elektrokemijsko redukcijo železovih (III) ionov v elementarno železo iz raztopine etilen glikola. Kinetiko in mehanizem procesa elektroredukcije smo raziskovali s cikličnimi in linearnimi polarizacijskimi tehnikami. Preučevali smo tudi vpliv temperature, hitrosti spreminjanja potenciala in koncentracije ionov železa (III) na postopek elektroredukcije. Opazovane vrednosti efektivne aktivacijske energije so pokazale, da je preiskovani postopek elektroredukcije kontroliran s procesi mešane kinetike. Poleg tega so rezultati analize SEM in rentgenske difrakcije potrdili, da lahko pod optimalnimi pogoji dosežemo odlaganje tankih filmov Fe. 